\title{
Result Classification
}

National Cancer Institute

\section{Source}

National Cancer Institute. Result Classification. NCI Thesaurus. Code C153143.

A category describing the result as disting uished by anatomical or physiological system, etiology, or purpose. 